\title{
Effect of oregano oil supplementation in diets formed using either crude soybean oil or acidulated soybean oil soapstock as source of energy on the growth performance parameters of broilers
}

\author{
Efecto de la suplementación con aceite de orégano en la dieta utilizando aceite de \\ soya crudo o aceite de soya acidulado como fuente de energía sobre los parámetros \\ productivos de crecimiento del pollo de engorda
}

\author{
F Escalera-Valente ${ }^{a}$, JL Loya-Olguín ${ }^{a}$, CA Carmona-Gasca ${ }^{a}$, \\ S Martínez-González ${ }^{\mathrm{a}}$, F Avila-Ramos ${ }^{\mathrm{b} *}$
}

\begin{abstract}
The type of oil used in the broiler diet is mainly based on its price; in the case of soybean oil (CSO), acidulated soybean oil soapstock (ASS) is cheaper. The aim of the present study was to evaluate the effect of oregano oil dietary supplementation when the diet contains either CSO or ASS as source of energy. 320 broilers Ross 308 were assigned to four groups: (1) CSO containing diet without oregano supplementation, (2) ASS containing diet without oregano supplementation, (3) CSO containing diet with oregano supplementation $(100 \mathrm{mg} / \mathrm{kg})$, and (4) ASS containing diet with oregano supplementation $(100 \mathrm{mg} / \mathrm{kg})$. The growth performance parameters were weekly recorded during the experiment. Data were analysed with a completely randomised design with $2 \times 2$ factorial arrangement and the mortality rates were adjusted using the arc-sine transformation to fulfill the analysis requirements. The results showed no effect of oregano oil (containing 30.7 and $9.7 \%$ of thymol and carvacrol, respectively) on feed intake, weight gain and feed conversion rate. A significant interaction of energy source by oregano oil supplementation was found in mortality rates $(\mathrm{P}<0.05)$; mortality was higher when the diet did not contain oregano oil and was formed using ASS. It can be concluded that the addition of $100 \mathrm{mg}$ of oregano oil per $\mathrm{kg}$ of feed did not have a positive effect on the growth performance parameters of broilers when the diet contained either crude soybean oil or acidulated soybean oil soapstock as sources of energy.

Key words: acidulated soybean oil soapstock, oregano oil, broiler, growth performance.
\end{abstract}

\begin{abstract}
RESUMEN. El tipo de aceite utilizado en la alimentación de los pollos de engorda se basa principalmente en su precio; en el caso del aceite de soya crudo (CSO) el aceite acidificado de soya (ASS) es más económico. El objetivo del estudio fue evaluar el efecto del aceite de orégano adicionado en la dieta cuando contiene CSO o ASS como fuente de energía. 320 pollos de engorda Ross fueron asignados a cuatro grupos: (1) CSO dieta sin adición de aceite de orégano, (2) ASS dieta sin adición de aceite de orégano, (3) CSO dieta adicionada con aceite de orégano (100 mg/kg), y (4) ASS dieta adicionada con aceite de orégano (100 mg/kg). Se registraron los parámetros de rendimiento productivo y los datos fueron analizados con un diseño completamente al azar con arreglo factorial $2 \times 2$ y los índices de mortalidad fueron ajustados utilizando la transformación arco-seno para cumpliar las bases para su análisis. Los resultados no mostraron efecto del aceite de orégano (su contenido 30,7\% y 9,7\% de timol y carvacrol, respectivamente) en consumo de alimento, ganancia de peso e índice de conversión alimenticia. Hubo interacción significativa del recurso de energía y la adición del aceite de orégano a la dieta en los índices de mortalidad $(\mathrm{P}<0,05)$; la mortalidad fue mayor cuando la dieta no contenía aceite de orégano y fue elaborada con ASS. Se concluye que la adición de $100 \mathrm{mg}$ de aceite de orégano por $\mathrm{kg}$ de alimento no tuvo un efecto positivo sobre los parámetros de rendimiento productivo de los pollos de engorda cuando la dieta es formulada con aceite de soya crudo $\mathrm{o}$ aceite acidificado de soya como fuente de energía.

Palabras clave: aceite acidificado de soya, aceite de orégano, pollo de engorda, rendimiento productivo.
\end{abstract}

\section{INTRODUCTION}

Plants contain an extensive variety of phytochemical compounds that can have beneficial effects on broilers' growth (Zakeri and Kashefi 2011). At present, they serve as an alternative to synthetic products in some European countries (Castañón 2007), since the use of antibiotics as

Accepted: 16.09.2015.

${ }^{a}$ Unidad Académica de Medicina Veterinaria y Zootecnia, Universidad Autónoma de Nayarit, Nayarit, México.

bivisión de Ciencias de la Vida, Programa de Medicina Veterinaria y Zootecnia, Universidad de Guanajuato, Guanajuato, México.

*Corresponding author: F Avila-Ramos; Ex Hacienda El Copal Km. 9 Carretera Irapuato-Silao, C.P. 36500, Irapuato, Guanajuato, México; ledifar@hotmail.com animal growth promoters was banned in 2006 by the EU (Marković et al 2009). An increase in the use of natural agents is possible in the future in other countries too, due to food safety issues related with general health risks and bacterial resistance (Cross et al 2007, Theuretzbacher 2013).

The use of various plant parts as dietary supplements, including culinary herbs may positively influence poultry health and productivity (Lee et al 2004, Freitas et al 2013, Mohiti-Asli and Ghanaatparast-Rashti 2015). Oregano oil is a natural additive obtained from leaves of Origanum vulgare, an aromatic plant well-known for its use as a food spice (Arcila et al 2004). The concentration of thymol and carvacrol in the oregano oil mainly influence its biological activity (Lee et al 2004). The levels of these compounds can be different varying according to their geographic 
region of origin, harvesting time, the extraction method used, season and altitude (Huyghebaert et al 2011).

Oregano oil dietary supplementation appears to improve weight gain and feed conversion rate, due to thymol and carvacrol, compounds that can cause an improvement of digestive enzymes' action and therefore of nutrient absorption in broilers (Jang et al 2007). However, these results vary, since the ingredients of the diet can affect the action of oregano oil (Abdel et al 2012). Increasing oregano oil from 50 to $300 \mathrm{mg}$ per $\mathrm{kg}$ of feed does not increase broiler productivity (Kirkpınar et al 2011), and this controversy with the previous results possibly is an impact of the source of energy used in the diet that can alter oregano oil dietary supplementation effect (Avila et al 2012).

In poultry various fats and essential fatty acids are used as a source of energy. Two of the most common fats used in poultry diets are animal/vegetable blends and crude oils, respectively (Blanch et al 1995). Acidulated soybean oil soapstock is one of the oil sources with the lowest cost for poultry diets, mainly because it is a by product from soybean oil refining (Hammond et al 2005). Feed intake, weight gain and feed conversion rate of broilers are not affected when this oil is used as source of energy (Thacker et al 1994, Baião and Lara 2005, Irandoust et al 2012). Compared to soybean oil, acidulated soybean oil soapstock contains high levels of free fatty acids (50\%), unsaponifiable matter and oxidized fatty acids (Bartov et al 1974, Pardio et al, 2001, Kessler et al 2009). The nature of used oils can affect the efficacy of natural antioxidants, therefore, the objective of this research was to evaluate the effect of oregano oil dietary supplementation either with a diet containing acidulated soybean oil soapstock or crude soybean oil as a source of energy on broiler growth performance parameters.

\section{MATERIAL AND METHODS}

\section{DETERMINATION OF THYMOL AND CARVACROL IN} OREGANO OIL

To identify and determine the amount of thymol and carvacrol, a gas chromatograph (Hewlett Packard P-6890, USA., California) coupled a mass spectrometer (ME; Hewlett Packard 7953., USA, California) containing a capillary column Hewlett Packard 5ms® (30 m length, $0.25 \mathrm{~mm}$ internal diameter and $0.25 \mu \mathrm{m}$ film thickness, USA., California) was used. The temperature of the GC injection port was $150{ }^{\circ} \mathrm{C}$, the initial temperature of the oven was $60^{\circ} \mathrm{C}$ during $5 \mathrm{~min}$, and was increased $20^{\circ} \mathrm{C}$ per min to reach $200{ }^{\circ} \mathrm{C}$. Helium was used as a carrier gas (Helio, Infra S.A. de C.V., State of Mexico, Mexico). The ME was operated in scan mode (range $\mathrm{m} / \mathrm{z}$ : 30-550) electron ionization $(70 \mathrm{eV})$. The temperatures of the quadrupole, ion source and interfase were 150,230 and $220^{\circ} \mathrm{C}$, respectively. $1 \mu \mathrm{L}$ of the sample was injected into the $\mathrm{GC}$ using the splitless mode, and the mass spectra obtained was compared with the NIST (Manion et al 2002) 2.0 database. Ions were identified, as well as their retention times and their relative abundance.

\section{BROILER PRODUCTION}

320 one-day old Ross 308 broilers were raised till the age of 42 days. Broilers were fed with basal corn-soybean meal diets containing either CSO or ASS (starter and grower-finisher) (Table 1). Broilers were randomly allocated to four treatments with four replications; each replication consisted of 20 birds, which were assigned to the control diet (CON) without supplementation containing either CSO or ASS or to the oregano supplemented diet containing either CSO or ASS (100 mg/kg) (ORE). Oregano oil was added in CSO or ASS before mixing them with the ingredients of the diet. Feed and water were provided ad libitum. Feed intake, weight gain and feed conversion rate were weekly recorded for each replication (Advance RH®, $150 \mathrm{~kg}$, digital scale, Mexico). Mortality rates were also daily recorded and presented as total mortality.

\section{STATISTICAL ANALYSIS}

The examined parameters were feed intake, weight gain, feed conversion rate and mortality rates. These results were analyzed using a completely randomized design with factorial arrangement $(2 \times 2)$ with oil type and oregano oil as factors. The GLM procedure of SAS for Windows 9.0 was used (SAS 2000). The mortality rates were adjusted using the arc-sine transformation and presented as total mortality (Figure 1). Mean comparisons were conducted using the Tukey's test.

The statistical model used was: $Y_{i j k}=\mu+T_{i}+\beta_{j}$ $+(T \beta)_{i j}+\varepsilon_{i j k}$ Where: $Y_{i j k}$ feed intake, weight gain, feed conversion rate and mortality rates, $\mu_{i}$ is the overall mean, $T_{i}$ is the oil type effect, $\beta_{i}$ is the oregano oil effect, $(T \beta)_{i j}$ effect of interaction betwen oil type and oregano oil, $E_{i j k}$ is the random error.

\section{RESULTS}

According to the analysis of the oregano oil used in the present study, it contained 30.7 of thymol and 9.7 of carvacrol with ion qualifiers: $9.93 \mathrm{~min}, 150$ (24), 91 (15.7), 136 (10.2) and $10.07 \mathrm{~min}, 150$ (31.4), 91 (13.1), 136 (10.2), respectively. Moreover, feed intake, weight gain and feed conversion rate were not affected by oregano oil dietary supplementation at 7, 14, 21, 28, 35 and 42 days of age (tables 2, 3 and 4). In mortality rates, there was an interaction of source of energy by oregano oil supplementation (figure $1 ; \mathrm{P}<0.05$ ); in case of ASS containing diet, oregano supplementation led to a significant decrease of mortality rates (10 vs $2.5 \%$ ). On the other hand, no effect of oregano supplementation in CSO containing diet was observed. 
Table 1. Chemical composition (\%) of crude soybean oil or soapstock containing diets.

Composición química (\%) de las dietas con aceite crudo de soya o aceite acidulado de soya.

\begin{tabular}{|c|c|c|c|c|}
\hline \multirow{2}{*}{ Ingredient } & \multicolumn{2}{|c|}{ Starter } & \multicolumn{2}{|c|}{ Grower-Finisher } \\
\hline & $\mathrm{CSO}^{1}$ & $\mathrm{ASS}^{2}$ & $\mathrm{CSO}$ & ASS \\
\hline Corn & 65.61 & 65.55 & 71.79 & 71.36 \\
\hline Soybean meal & 29.22 & 29.10 & 22.11 & 22.19 \\
\hline $\mathrm{CSO}$ & 1.00 & 0.00 & 1.86 & 0.00 \\
\hline ASS & 0.00 & 1.17 & 0.00 & 2.21 \\
\hline Calcium bicarbonate (38\%) & 1.64 & 1.64 & 1.52 & 1.51 \\
\hline Dicalcium phospate $(18 / 21)$ & 1.49 & 1.49 & 1.30 & 1.30 \\
\hline Salt & 0.30 & 0.30 & 0.30 & 0.30 \\
\hline Mineral premix ${ }^{3}$ & 0.06 & 0.06 & 0.06 & 0.06 \\
\hline Vitamin premix ${ }^{4}$ & 0.05 & 0.05 & 0.05 & 0.05 \\
\hline DL-Methionine & 0.30 & 0.30 & 0.18 & 0.18 \\
\hline L-lysine $\mathrm{HCl}$ & 0.29 & 0.30 & 0.19 & 0.18 \\
\hline Xantophyls ${ }^{5}$ & 0.00 & 0.00 & 0.60 & 0.60 \\
\hline Coccidiostate & 0.05 & 0.05 & 0.05 & 0.05 \\
\hline \multicolumn{5}{|l|}{ Nutrient composition } \\
\hline Metabolizable energy (Mcal/kg) & 3.00 & 3.00 & 3.10 & 3.10 \\
\hline Crude Protein & 20.06 & 20.00 & 17.00 & 17.00 \\
\hline Calcium & 1.00 & 1.00 & 0.90 & 0.90 \\
\hline Linoleic acid & 1.90 & 1.72 & 2.46 & 2.13 \\
\hline Lysine & 1.30 & 1.30 & 1.00 & 1.00 \\
\hline Methionine + Cystine & 0.95 & 0.95 & 0.75 & 0.75 \\
\hline Available phosphorous & 0.45 & 0.45 & 0.45 & 0.45 \\
\hline Hystidine & 0.51 & 0.51 & 0.43 & 0.43 \\
\hline Triptophane & 0.27 & 0.27 & 0.23 & 0.23 \\
\hline Threonine & 0.84 & 0.84 & 0.73 & 0.73 \\
\hline Arginine & 1.31 & 1.31 & 1.08 & 1.08 \\
\hline
\end{tabular}

${ }^{1} \mathrm{CSO}=$ crude soybean oil.

${ }^{2} \mathrm{ASS}=$ acidulated soybean oil soapstock

${ }^{3}$ Amount in mg per kg of feed: Se 0.27, I 2, Cu 8, Fe 50, Zn 80, Mn 80, and Co 0.2 (Trouw Nutrition, Nuevo León, México).

${ }^{4}$ Amount per $\mathrm{kg}$ of feed: A, $12000 \mathrm{UI}, \mathrm{D}_{3}, 3100 \mathrm{UI}_{3}, \mathrm{~K}_{3}, 5 \mathrm{mg}$, thiamine, $2 \mathrm{mg}$, riboflavin, $12 \mathrm{mg}$, pantothenic acid, $21 \mathrm{mg}$, pyridoxine, $2.6 \mathrm{mg}$, folic acid, $1.5 \mathrm{mg}, \mathrm{B}_{12}, 0.018 \mathrm{mg}$, and biotin, $0.15 \mathrm{mg}$ (Ajinomoto, DF, México).

${ }^{5}$ Amount per kg of feed: yellow pigment $15 \mathrm{~g}$ (Alcos, DF, México).

\section{DISCUSSION}

The oregano oil used in the present study contained 30.7 and $9.7 \%$ of thymol and carvacrol, respectively, levels that are already reported in oils obtained in the region of Jalisco in Mexico (Arcila et al 2004, Arana et al 2010). However, these levels are lower compared to the oregano oil harvested from Europe that can contain until $80 \%$ of thymol and carvacrol (Abu-Lafi et al 2008). In the majority of oregano oils, the amount of thymol is higher compared to that of carvacrol. The two compounds have a negative correlation with each other, so when carvacrol increases, thymol decreases. This variation can cause different effects on broilers, since high levels of carvacrol are related with a higher weight gain and an increase of gastric secretions, therefore, the dietary nutrients are efficiently absorbed (Russo et al 1998). No effects were observed in the present study on the examined growth performance parameters, partially explained by this variation in thymol and carvacrol rates.

The obtained results indicated that the addition of oregano oil at the level of $100 \mathrm{mg}$ per $\mathrm{kg}$ of feed did not increase feed intake, weight gain and feed conversion rate of chickens either when the diet contained crude soybean oil or acidulated soybean oil soapstock as source of energy (Kessler et al 2009). These results also confirmed that oregano essential oil can be fed to broilers without detrimental effects on their productivity. No negative effects on productivity variables were also observed in other studies conducted with different levels of oregano oil (per kg of feed); from 50 to $1000 \mathrm{ml}$ (Botsoglou et al 2002, Hernández et al 2004, Marčincák et al 2008), 200 $\mathrm{mg}$ (Jang et al 2007), 300, 500 and $1000 \mathrm{mg}$ (Cross et al 2007, Freitas et al 2013). In general, oregano oil appears to increase the stimulation of digestive enzymes in the intestinal mucosa, therefore nutrient absorption in the 


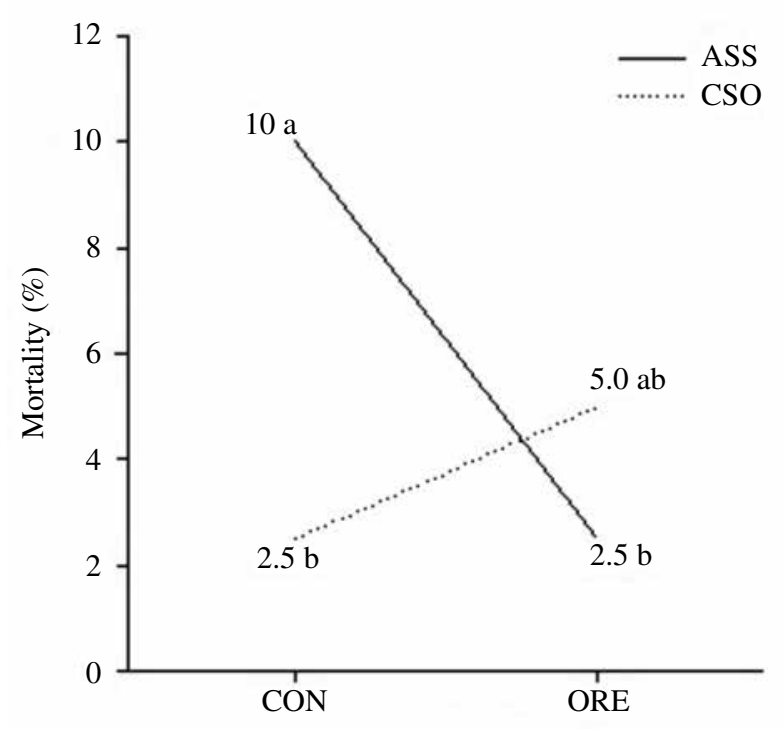

Figure 1. Mortality rates in the different groups of broilers. Tasa de mortalidad en diferentes grupos de pollos de engorda.

ASS $=$ acidulated soybean oil soapstock, $\mathrm{CSO}=$ crude soybean oil. $\mathrm{CON}=$ control, $\mathrm{ARE}=$ oregano oil at $100 \mathrm{mg} / \mathrm{kg}$.

${ }^{\mathrm{a}, \mathrm{b}}$ Means with different superscripts are statistically different $(\mathrm{P}<0.05)$.

digestive system of broilers can be improved (Bhat et al 1984, Sambaiah and Srinivasan 1991, Platel and Srinivasan 1996). However, the observation of insignificant effects of oregano oil might be a result of the conditions of the present study; well-nourished birds and disinfected environment. It has also been also well documented that dietary antibiotics such penicillin do not promote growth performance when animals were raised in germ free conditions (Coates et al 1963). Similar to antibiotics, dietary oregano oil as a growth promoter could not give beneficial results when birds are kept at optimal conditions such as highly digestible diets and clean conditions (Botsoglou et al 2002). Therefore, extensive research is necessary to highlight the factors and the metabolic processes that influence feed intake, weight gain and feed conversion rate when the diet contains different oils as ingredients.

Oregano oil dietary supplementation could be associated with an improvement in feed efficiency (Lee et al 2004). However, the impact of essential oils on the performance parameters has generally been inconsistent, at least partially due to their hydrophobic nature, which makes their delivery to the intestine ineffective (Kohlert et al 2000, Michiels et al 2008). The ASS is a byproduct of the soybean oil and it is obtained through the alkaline neutralization of the CSO. ASS contains higher levels of free fatty acids (50\%) compared to CSO, a fact that influences the nutritive value of the ingredients in the diet (Blanch et al 1995). The inclusion of ASS as a source of energy in the diet could be associated with a lower absorption of thymol and carvacrol by broilers compared to CSO containing diets (Wiseman and Salvador 1991). This process has been already observed with vitamin E (Drevon 1991) and the compounds of oregano oil may be similarly influenced. ASS does not have enough monoglycerides to be combined with all free fatty acids when they are offered as the only fat source (Blanch et al 1995, Baião and Lara 2005). Besides, broilers can not absorb the same amount of nutrients when a fat of lower quality is added in the diet (Baião and Lara 2005).

Table 2. Feed intake $(\mathrm{kg})$ of broilers fed with crude soybean oil or acidulated soybean oil soapstock as a source of energy, further supplemented or not with oregano oil (means $\pm \mathrm{SE}$ ).

Consumo de alimento $(\mathrm{kg})$ de los pollos alimentados con aceite crudo de soya o aceite acidulado de soya como fuente de energía, adicionada o no con aceite de orégano (medias $\pm \mathrm{DE}$ ).

\begin{tabular}{|c|c|c|c|c|c|c|c|}
\hline \multirow{2}{*}{ Treatment } & & \multicolumn{3}{|c|}{ Starter } & \multicolumn{3}{|c|}{ Grower-finisher } \\
\hline & & 7 & 14 & 21 & 28 & 35 & 42 \\
\hline \multirow[t]{2}{*}{$\mathrm{CSO}^{1}$} & $\mathrm{CON}^{3}$ & 0.155 & 0.414 & 0.596 & 0.843 & 1.070 & 1.253 \\
\hline & $\mathrm{ORE}^{4}$ & 0.133 & 0.435 & 0.605 & 0.867 & 1.097 & 1.252 \\
\hline \multirow[t]{2}{*}{$\mathrm{ASS}^{2}$} & $\mathrm{CON}$ & 0.151 & 0.406 & 0.579 & 0.808 & 1.040 & 1.214 \\
\hline & ORE & 0.153 & 0.407 & 0.584 & 0.834 & 1.063 & 1.223 \\
\hline $\mathrm{P}>\mathrm{F}$ & & 0.604 & 0.239 & 0.413 & 0.651 & 0.511 & 0.292 \\
\hline SEM & & 0.006 & 0.027 & 0.034 & 0.034 & 0.029 & 0.017 \\
\hline Parameters & & \multicolumn{6}{|c|}{ Probabilities (P values) } \\
\hline Source of energy (S) & & 0.525 & 0.118 & 0.118 & 0.248 & 0.238 & 0.067 \\
\hline Oregano Oil $(\mathrm{O})$ & & 0.455 & 0.320 & 0.320 & 0.663 & 0.364 & 0.788 \\
\hline $\mathrm{S} \times \mathrm{O}$ & & 0.362 & 0.353 & 0.353 & 0.912 & 0.939 & 0.809 \\
\hline
\end{tabular}

${ }^{1} \mathrm{CSO}=$ crude soybean oil.

${ }^{2} \mathrm{ASS}=$ acidulated soybean oil soapstock.

${ }^{3} \mathrm{CON}=$ control.

${ }^{4} \mathrm{ORE}=$ oregano essential oil at $100 \mathrm{mg} / \mathrm{kg}$. 
Table 3. Weight gain $(\mathrm{kg})$ of broilers fed with crude soybean oil or acidulated soybean oil soapstock as a source of energy, further supplemented or not with oregano oil (means $\pm \mathrm{SE}$ ).

Ganancia de peso $(\mathrm{kg})$ de pollos alimentados con aceite de soya crudo o aceite acidulado de soya como fuente de energía, adicionada o no con aceite de orégano (medias $\pm \mathrm{DE}$ ).

\begin{tabular}{|c|c|c|c|c|c|c|c|}
\hline \multirow{2}{*}{ Treatment } & & \multicolumn{3}{|c|}{ Starter } & \multicolumn{3}{|c|}{ Grower-finisher } \\
\hline & & 7 & 14 & 21 & 28 & 35 & 42 \\
\hline \multirow[t]{2}{*}{$\mathrm{CSO}^{1}$} & $\mathrm{CON}^{3}$ & 0.116 & 0.274 & 0.376 & 0.431 & 0.563 & 0.568 \\
\hline & $\mathrm{ORE}^{4}$ & 0.115 & 0.272 & 0.393 & 0.427 & 0.567 & 0.609 \\
\hline \multirow[t]{2}{*}{$\mathrm{ASS}^{2}$} & $\mathrm{CON}$ & 0.107 & 0.25 & 0.357 & 0.429 & 0.566 & 0.674 \\
\hline & ORE & 0.118 & 0.266 & 0.363 & 0.411 & 0.579 & 0.612 \\
\hline $\mathrm{P}>\mathrm{F}$ & & 0.500 & 0.399 & 0.775 & 0.914 & 0.922 & 0.379 \\
\hline SEM & & 0.017 & 0.030 & 0.034 & 0.033 & 0.027 & 0.005 \\
\hline Parameters & & \multicolumn{6}{|c|}{ Probabilities ( $P$ values $)$} \\
\hline Source of energy (S) & & 0.548 & 0.177 & 0.371 & 0.691 & 0.692 & 0.212 \\
\hline Oregano Oil (O) & & 0.345 & 0.550 & 0.654 & 0.622 & 0.624 & 0.804 \\
\hline $\mathrm{S} \times \mathrm{O}$ & & 0.303 & 0.396 & 0.844 & 0.771 & 0.816 & 0.235 \\
\hline
\end{tabular}

${ }^{1} \mathrm{CSO}=$ crude soybean oil.

${ }^{2} \mathrm{ASS}=$ acidulated soybean oil soapstock

${ }^{3} \mathrm{CON}=$ control.

${ }^{4} \mathrm{ORE}=$ oregano essential oil at $100 \mathrm{mg} / \mathrm{kg}$.

Table 4. Feed conversion rate of broilers fed with crude soybean oil or acidulated soybean oil soapstock as a source of energy, further supplemented or not with oregano oil (means $\pm \mathrm{SE}$ ).

Tasa de conversión alimenticia $(\mathrm{kg})$ de pollos alimentados con aceite de soya crudo o aceite acidulado de soya como fuente de energía, adicionada o no con aceite de orégano (medias $\pm \mathrm{DE}$ ).

\begin{tabular}{|c|c|c|c|c|c|c|c|}
\hline \multirow{2}{*}{ Treatments } & & \multicolumn{3}{|c|}{ Starter } & \multicolumn{3}{|c|}{ Grower-finisher } \\
\hline & & 7 & 14 & 21 & 28 & 35 & 42 \\
\hline \multirow[t]{2}{*}{$\overline{\mathrm{CSO}^{1}}$} & $\mathrm{CON}^{3}$ & 1.135 & 1.507 & 1.592 & 1.960 & 1.905 & 2.205 \\
\hline & $\mathrm{ORE}^{4}$ & 1.338 & 1.605 & 1.540 & 2.042 & 1.932 & 2.062 \\
\hline \multirow[t]{2}{*}{$\mathrm{ASS}^{2}$} & $\mathrm{CON}$ & 1.450 & 1.645 & 1.555 & 1.882 & 1.845 & 2.000 \\
\hline & ORE & 1.310 & 1.532 & 1.542 & 2.062 & 1.835 & 1.990 \\
\hline $\operatorname{Pr}>\mathrm{F}$ & & 0.226 & 0.570 & 0.814 & 0.440 & 0.336 & 0.219 \\
\hline SEM5 & & 0.023 & 0.032 & 0.034 & 0.031 & 0.023 & 0.014 \\
\hline Parameters & & \multicolumn{6}{|c|}{ Probabilities $(P$ values $)$} \\
\hline Source of energy (S) & & 0.175 & 0.676 & 0.385 & 0.738 & 0.086 & 0.091 \\
\hline Oregano Oil (O) & & 0.117 & 0.923 & 0.818 & 0.144 & 0.838 & 0.918 \\
\hline $\mathrm{S} \times \mathrm{O}$ & & 0.771 & 0.192 & 0.781 & 0.572 & 0.664 & 0.214 \\
\hline
\end{tabular}

${ }^{1} \mathrm{CSO}=$ crude soybean oil.

${ }^{2} \mathrm{ASS}=$ acidulated soybean oil soapstock.

${ }^{3} \mathrm{CON}=$ control.

${ }^{4} \mathrm{ORE}=$ oregano essential oil at $100 \mathrm{mg} / \mathrm{kg}$.

As it is shown it figure 1, birds fed with the ASS containing diet without oregano essential oil supplementation had the higher mortality rates compared to the other groups. However, the addition of oregano oil appeared to diminish this negative effect of ASS. Therefore, although the use of ASS causes increased mortality rates, the addition of oregano at the level of $100 \mathrm{mg}$ per $\mathrm{kg}$ of feed could serve as an alternative when ASS is used as source of energy.
It can be concluded that the addition of oregano oil as a natural additive in diets containing either crude soybean oil or acidulated soybean oil soapstock as a source of energy did not affect the growth performance parameters in broilers. Therefore, acidulated soybean oil soapstock can be used as an inexpensive source of energy in broilers' diets. The results concerning mortality rates suggest that extensive research is necessary to explain the interaction 
of oregano oil supplementation by the source of oil added in the diets and their effects on health status of broilers.

\section{REFERENCES}

Abdel WA, S Kehraus, F Hippenstiel, KH Südekum. 2012. Effects of thyme and oregano on growth performance of broilers from 4 to 42 days of age and on microbial counts in crop, small intestine and caecum of 42-day-old broilers. Anim Feed Sci Technol 178, 198-202.

Abu-Lafi S, I Odeh, H Dewik, M Qabajah, L Hanus, VM Dembitsky. 2008. Thymol and carvacrol production from leaves of wild Palestinian majorana syriaca. Bioresource Technol 99, 3914-3918.

Arana SA, ME Estarrón, ENV Obledo, EC Padilla, RV Silva, EC Lugo. 2010. Antimicrobial and antioxidant activities of Mexican oregano essential oils (Lippia Graveolens H. B. K.) with different composition when microencapsulated in beta-cyclodextrin. Lett Appl Microbiol 50, 585-590.

Arcila LCC, G Pina, LS Lecoma, EG Mejia. 2004. El orégano: Propiedades, composición, y actividad biológica de sus componentes. Arch Latinoam Nutr 54, 100-111.

Ávila RF, AM Pro, EM Sosa, JMG Cuca, CMP Becerril, JLV Figueroa, CG Narciso. 2012. Dietary oregano essential oil and vitamin E effect on the lipid oxidation stability of cooked chicken breast meat. Poult Sci 91, 505-511.

Baião NC, LJC Lara. 2005. Oil and fat in broiler nutrition. Brit Poultry Sci 7, 129-141.

Bartov I, B Lipstein, S Bornstein. 1974. Differential effects of dietary acidulated soybean oil soapstock, cottonseed oil soapstock and tallow on broiler carcass fat characteristics. Poult Sci 53, 115-124.

Botsoglou NA, P Florou-Paneri, E Christaki, DJ Fletouris, AB Spais. 2002. Effect of dietary oregano essential oil on performance of chickens and on iron-induced lipid oxidation of breast, thigh, and abdominal fat tissues. Br Poult Sci 43, 223-230.

Bhat BG, MR Srinivasan, N Chandrasekhara. 1984. Influence of curcumin and capsaicin on the composition and secretion of bile in rats. $J$ Food Sci Tec 21, 225-227.

Blanch A, AC Barroeta, MD Baucells, F Puchal. 1995. The nutritive value of dietary fats in relation to their chemical composition. Apparent fat availability and metabolizable energy in two-week-old chicks. Poult Sci 74, 1335-1340.

Castañón JIR. 2007. History of the use of antibiotic as growth promoters in european poultry feeds. Poult Sci 86, 2466-2471.

Coates ME, R Fuller, GF Harrison, M Lev, SF Suffolk. 1963. A comparison of the growth of chicks in the Gustafsson germ-free apparatus and in a conventional environment, with and without dietary supplements of penicillin. Br J Nutr 17, 141-150.

Cross DE, RM McDevitt, K Hillman, T Acamovic. 2007. The effect of herbs and their associated essential oils on perfor-mance, dietary digestibility, and gut microflora in chickens from 7 to 28 days of age. Br Poult Sci 48, 496-506.

Drevon CA. 1991. Absorption, transport and metabolism of vitamin E. Free Radic Res Commun 14, 229-246.

Freitas ZS, DS Ribeiro, MRR Alves, MS Aparecida, MZ Santos, GC Luiz. 2013. Oregano essential oil as antimicrobial agent in broilers diet. Arch Vet Sci 18, 01-07.

Hammond EG, LA Johnson, C Su, T Wang, PJ White. 2005. Soybean Oil. In:Shahidi F (ed). Bailey's Industrial Oil and Fat Products. John Wiley and Sons Inc., Hoboken, NJ, USA, Pp 577-653.

Hernández F, J Madrid, V García, J Orengo, MD Megías. 2004. Influence of two plant extracts on broilers performance, digestibility, and digestive organ size. Poult Sci 83, 169-174.

Huyghebaert G, R Ducatelle, FV Immerseel. 2011. An update on alternatives to antimicrobial growth promoters for broilers. Vet $J 187,182-188$

Irandoust H, HA Samie, HR Rahmani, MA Edriss, GG Mateos. 2012. Influence of source of fat and supplementation of the diet with vitamin $\mathrm{E}$ and $\mathrm{C}$ on performance and egg quality of laying hens from forty four to fifty six weeks of age. Anim Feed Sci Technol 177, 75-85.

Jang IS, YH Ko, SY Kang, CY Lee. 2007. Effect of a commercial essential oil on growth performance, digestive enzyme activity and microflora intestinal population in broiler chickens. Anim Feed Sci Technol 134, 304-315.

Kessler AM, DS Lubisco, MM Vieira, AML Ribeiro, AM Penz. 2009. Fatty-acid composition of free-choice starter broiler diets. $\mathrm{Br}$ Poult Sci 11, 31-38.

Kırkpınar F, HÜ Bora, Ö Güven. 2011. Effects of oregano and garlic essential oils on performance, carcase, organ and blood characteristics and intestinal microflora of broilers. Livest Prod Sci 137, 219-225.

Kohlert C, VI Rensen, R Marz, G Schindler, EU Graefe, M Veit. 2000. Bioavailability and pharmacokinetics of natural volatile terpenes in animals and humans. Planta Med 66, 495-505.

Lee KW, H Everts, AC Beynen. 2004. Essential oils in broiler nutrition. Int J Poult Sci 3, 738-752.

Manion JA, RE Huie, RD Levin, DR Burgess, VL Orkin, W Tsang, WS McGivern, JW Hudgens, VD Knyazev, DB Atkinson, E Chai, AM Tereza, CY Lin, TC Allison, WG Mallard, F Westley, JT Herron, RF Hampson, DH Frizzell. 2002. NIST Chemical Kinetics Database, Standard Reference Database 17. Version 7.0 (Web Version), Release 1.6.8. National Institute of Standards and Technology, Gaithersburg, Maryland, USA.

Marčincák S, R Cabadaj, P Popelka, L Soltysova. 2008. Antioxidative effect of oregano supplemented to broilers on oxidative stability of poultry meat. Slov Vet Res 45, 61-66.

Marković R, D Šefer, M Krstić, B Petrujkić. 2009. Effect of different growth promoters on broiler performance and gut morphology. Arch Med Vet 41, 163-169.

Michiels J, J Missotten, N Dierick, D Fremaut, P Maene, S De Smet. 2008. In vitro degradation and in vivo passage kinetics of carvacrol, thymol, eugenol and transcinnnamaldehyde along the gastrointestinal tract of piglets. J Sci Food Agric 88, 2371-2381.

Mohiti-Asli M, M Ghanaatparast-Rashti. 2015. Dietary oregano essential oil alleviates experimentally induced coccidiosis in broilers. Prev Vet Med 120, 195-202.

Pardio VT, LA Landin, KN Waliszewski, C Badillo, F Pérez-Gil. 2001. The effect of acidified soapstocks on feed conversion and broiler skin pigmentation. Poult Sci 80, 1236-1239.

Platel K, K Srinivasan. 1996. Influence of dietary spices or their active principles on digestive enzymes of small intestinal mucosa in rats. Int J Food Sci Nutr 47, 55-59.

Russo MG, C Galletti, P Bocchini, A Carnacini. 1998. Essential oils chemical composition of wild populations of Italian oregano spice (Origanum vulgare ssp, hirtum (Link) Lestwart): A preliminary evaluation of their use in chemotaxonomy by cluster analysis. I. inflorescences. J Agric Food Chem 46, 3741-3746.

Sambaiah K, K Srinivasan. 1991. Secretion and composition of bile in rats fed diets containing spices. J Food Sci Technol 28, 35-38.

SAS. 2000. SAS/STAT User's Guide: Version $6.4^{\text {th }}$ ed. SAS Institute Inc., Cary, North Carolina, USA.

Thacker PA, GL Campbell, Y Xu. 1994. Composition and nutritive value of acidulated fatty acids, degummed canola oils and tallow as energy sources for starting broiler chicks. Anim Feed Sci Technol 46, 251-260.

Theuretzbacher U. 2013. Global antibacterial resistance: The neverending story. J Global Antimicrob Resistance 1, 63-69.

Wiseman J, F Salvador. 1991. The influence of free fatty acid content and degree of saturation on the apparent metabolizable energy of fats fed to broiler chicks. Br Poult Sci 30, 653-662.

Zakeri A, P Kashefi. 2011. The comparative effects of five growth promoters on broiler chickens humoral immunity and performance. J Anim Vet Adv 10, 1097-1101. 